\title{
Design and feasibility verification of regenerative system of electric thermal storage boiler for peak shaving in summer in power plant
}

\author{
Yingying Yao ${ }^{1, *}$, Xiaobo Wang ${ }^{2}$, Zhongzhou Dou ${ }^{1}$, Hang Wang ${ }^{1}$, and Zeyang $\mathrm{Li}^{1}$ \\ ${ }^{1}$ Jilin Province Electric Power Science Research Institute Co, Ltd, Changchun, Jilin, China \\ ${ }^{2}$ China Northeast Municipal Engineering Design and Research Institute Co., Ltd. Changchun, Jilin, \\ China
}

\begin{abstract}
During the heating period, the thermal storage electric boiler helps the thermal power units to participate in the deep peak regulation by converting the electric energy into heat energy for heating users, but in the non-heating period, the thermal storage electric boiler can not operate because there is no heat user, as a result, the thermal storage electric boiler is shut down in summer, and can not assist the thermal power unit to participate in the deep peak regulation. Therefore, this paper designs an electric thermal storage boiler regenerative system for peak shaving in summer. In this regenerative system, electric boiler is used to heat circulating water in heating period, and electric boiler is used to heat condensed water in non-heating period, and in the non-heating period, the number of low-pressure heaters can be adjusted according to the load and heat storage capacity of the units, so that the electric boiler can assist the thermal power units to participate in the deep peak regulation throughout the year, taking a $350 \mathrm{MW}$ unit with $70 \mathrm{MW}$ regenerative electric boiler as an example, the heat exchange capacity is calculated to verify the feasibility of the regenerative system. In this paper, a new method of heating condensate by regenerative electric boiler in non-heating period is proposed to solve the problem that the new energy can not be used and the energy is wasted in summer.
\end{abstract}

\section{Introduction}

In order to promote the development of new energy in our country and focus on solving the problem of new energy consumption in the "three north" region, the state and local governments have adopted a series of measures to promote the development of new energy, to solve the problem of new energy development from various angles such as technology route and industrial policy ${ }^{[1-4]}$. Thermal storage boilers are widely used in cogeneration units because of their fast start-up and high load ${ }^{[5-7]}$. During the heating period in winter, the balance of peak-valley electricity and wind-photovoltaic energy dissipation can be

\footnotetext{
*Corresponding author: $823764947 @$ qq.com
} 
carried out in the power grid of electric boiler, and the flexibility of cogeneration unit can be increased ${ }^{[8-9]}$. But in the non-heating period, the peak-load regulation requirements and heating load of the unit are reduced, which leads to the shutdown of the thermal storage electric boiler in the non-heating period and the decrease of the equipment utilization ratio. Therefore, this paper presents a regenerative system of electric thermal storage boiler for peak load regulation in summer, which is used to solve the technical problem of energy waste caused by waste wind power in summer.

\section{System design}

The main starting point of the design of regenerative electric boiler regenerative system is the coupling of regenerative electric boiler with heating network circulation system and condensate system, in winter, the auxiliary units of Electric Boiler and heat network circulation system are used to regulate the peak load and ensure the heat supply. In summer, the auxiliary units of Electric Boiler and condensate system are used to regulate the peak load and improve the utilization efficiency of thermal storage electric boiler. The regenerative system of the electric thermal storage boiler used for peak shaving in the power plant can ensure the auxiliary units of the electric boiler to participate in deep peak shaving in summer.

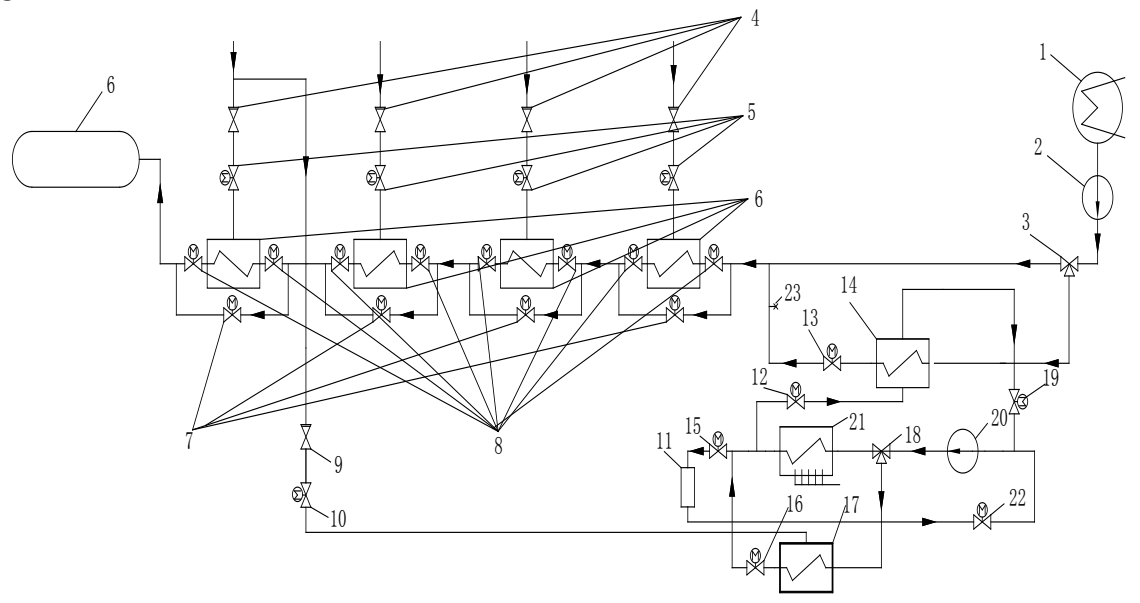

Fig. 1. Regenerative system of electric thermal storage boiler for peak shaving in summer.

In figure $1: 1$ is the condenser, 2 is the condensate pump, 3 is the condensate three-way Valve, 4 is the low-pressure heater extraction steam backstop door, 5 is the low-pressure heater inlet steam electric door, 6 is the low-pressure heater, 7 is the low-pressure heater bypass electric door, 8 is electric inlet and outlet doors for low pressure heaters, 9 is electric inlet and outlet doors for heat-supply network heaters, 10 is electric inlet doors for heatsupply network heaters, 11 is water for heat users, 12 is electric inlet doors for circulating water side of heat-supply networks for water heat exchangers, 13 is water heat exchanger condensing water side outlet electric door, 14 is water heat exchanger, 15 is heat storage electric boiler circulating water outlet electric door, 16 is heat network heater outlet electric door, 17 is heat network heater, 18 is the heat network circulating water pump three-way Valve, 19 is the water heat exchanger circulating water side outlet electric door, 20 is the heat network circulating water pump, 21 is the heat storage electric boiler, 22 is the heat network circulating water return electric door, 23 is the water for water heat exchanger condensation water side outlet temperature measurement point. 


\section{System operation}

The operation mode of the electric thermal storage boiler used for peak shaving in summer includes the operation mode in heating period and that in non-heating period.

During the heating period, the electric door at the inlet of the circulating water side of the water-water heat exchanger heat network, the electric door at the outlet of the condensing water side of the water heat exchanger, the electric door at the outlet of the circulating water side of the water heat exchanger heat network and the three-way valve of the condensing water to the side of the water heat exchanger are closed, operation Relationship between isolated water-water heat exchanger and system.

During the low load of the power network during the heating period, on the one hand, the heat storage electric boiler converts the surplus electric energy into heat energy stored in the heat storage body, on the other hand, it closes the electric door of the circulating water outlet of the heat storage electric boiler's heat network, open the electric inlet steam door of the heating network heater, the electric outlet door of the heating network heater and the three-way valve of the circulating water pump of the heating network to the side of the heating network heater, reduce the amount of electricity on the grid in two ways.

During the heating period when the load of the power network is at its peak, the electric door of the circulating water outlet of the heat storage network of the heat storage boiler is opened, and the opening of the three-way valve of the circulating water pump of the heat storage network is adjusted according to the heat storage capacity of the heat storage boiler and the heating demand of the heat users, that is to adjust the circulating water flow into the heating network heater and the thermal storage electric boiler, to reduce the amount of steam pumped into the heating network heater, to increase the generating capacity of units and to increase the amount of electricity connected to the network on the premise of meeting the heating demand.

In the non-heating period, close the electric inlet steam door of the heating network heater, the electric door of the circulating water outlet of the heating network boiler, the electric door of the outlet of the Heating Network Heater and the three-way Valve of the circulating water pump of the heating network to the side of the heating network heater, operation Relationship between isolated heat net heater and system.

When the load of power grid is low in non-heating period, close the electric door at the inlet of the circulating water side of the water-water heat exchanger, the electric door at the outlet of the condensate water side of the water heat exchanger, the three-way valve of the circulating water pump, the electric door at the outlet of the circulating water side of the water-water heat exchanger and the three-way valve of the condensate water to the side of the water-water heat exchanger, the surplus electric energy is converted into heat energy and stored in the heat storage body, and the condensed water is heated through the lowpressure heater without reducing the amount of steam extracted from the low-pressure heater and the amount of electricity connected to the network.

During peak load of power grid in non-heating period, open water-water heat exchanger heat network circulating water side entrance electric door, water-water heat exchanger heat network circulating water side exit electric door, hot network circulating water pump threeway valve leading to thermal storage electric boiler side and water-water heat exchanger condensate side exit electric door, then, according to the load of the unit and the heat storage capacity of the electric boiler, the opening of the condensate three-way valve leading to the low-pressure heater and the water-water heat exchanger is adjusted, that is, the condensate flow rate leading to the low-pressure heater and the water-water heat exchanger is adjusted, open or close the electric door by-pass of the low-pressure heater or the electric door of the inlet and outlet of the low-pressure heater, that is to determine the 
operation of the number of low-pressure heaters, reduce the unit steam extraction, increase the power grid.

\section{Feasibility check}

Taking a 350MW unit as an example, during the non-heating period, the regenerative power of the electric heat storage furnace of the unit is $70 \mathrm{MW}$. The unit can operate stably under the condition of $30 \%$ tha at the lowest, the surplus electricity and the abandoned wind power are stored to the electric heat storage furnace, the daily heat storage time is 5 hours, the daily heat storage time is 5 hours, the heat storage efficiency is $95 \%$, then the electric heat storage furnace can release the maximum heat of $33250 \mathrm{~kW} \cdot \mathrm{h}$ per day.

The normal operating condition of the system is 50\% THA, the condensate flow rate is $390 \mathrm{t} / \mathrm{h}$, the outlet water temperature of the condensate pump is $33^{\circ} \mathrm{C}$, the condensate water temperature before the deaerator is $128^{\circ} \mathrm{C}$, and the enthalpy difference between the outlet of the condensate pump and that before the deaerator is $400 \mathrm{~kJ} / \mathrm{kg}$, it is assumed that $40 \%$ of the total condensed water flows through the water-water heat exchanger during the heat release period of the electric storage furnace, and the heat transfer power of the water-water heat exchanger is $17.7 \mathrm{MW}$.

The temperature of circulating water at the outlet of the electric heat storage boiler is $200^{\circ} \mathrm{C}$, the temperature of circulating water drainage is $50^{\circ} \mathrm{C}$, the heat transfer Coefficient $\mathrm{K}$ of the water-water heat exchanger is $800 \mathrm{~W} / \mathrm{W} /\left(\mathrm{m}^{2} \cdot \mathrm{K}\right)$ for counterflow heat transfer, and the temperature of the condensing water at the outlet of the condenser is $33^{\circ} \mathrm{C}$, the outlet condensation water temperature of the low pressure heater is $128^{\circ} \mathrm{C}$. To sum up, the inlet water temperature at the cold end of the water-water heat exchanger is $33^{\circ} \mathrm{C}$, the outlet water temperature is $128^{\circ} \mathrm{C}$, the flow rate is $160 \mathrm{t} / \mathrm{h}$, the inlet water temperature at the hot end is $200^{\circ} \mathrm{C}$, the outlet water temperature is $50^{\circ} \mathrm{C}$, and the flow rate is $100.8 \mathrm{t} / \mathrm{h}$. Based on the specific heat capacity of the water, the heat capacity at the hot end is 117200 , the cold end has a thermal capacity of 185900 and the number of heat transfer units NTU is 3.612 .

The heat capacity ratio is calculated as follows:

$$
R_{\mathrm{c}}=\frac{W_{1}}{W_{2}}=0.563
$$

The formula for calculating the heat transfer efficiency is:

$$
\varepsilon=\frac{t_{1}^{\prime}-t_{1}^{\prime \prime}}{t_{1}^{1}-t_{2}^{\prime}}=0.898
$$

According to the formula:

$$
\varepsilon=\frac{1-\exp \left[-N T U \times\left(1-R_{c}\right)\right]}{1-R_{c} \exp \left[-N T U \times\left(1-R_{c}\right)\right]}
$$

Heat transfer area of water-water heat exchanger:

$$
F=\frac{N T U \cdot W_{\min }}{K}=529 \mathrm{~m}^{2}
$$


Taking into account that the water-water heat exchanger contains $5 \%$ heat loss, if the electric heat storage boiler is used to store all the heat every day, the daily heat exchange capacity is $315000 \mathrm{~kW}$, and the heat can be released for about 18 hours, considering that the heat exchange effect of the electric heat storage boiler is poor when the temperature of the heat storage brick is low, the daily heat exchange time can still reach more than 10 hours, that is to say, the auxiliary unit of Regenerative Electric Boiler can participate in the deep peak regulation for 10 hours every day when it runs in summer.

\section{Conclusion}

(1) in this paper, an electric thermal storage boiler reheat system is designed, which is used for peak shaving in summer in power plant, in heating period, the auxiliary units of Regenerative Electric Boiler and circulating water system of heating network are used to participate in the deep peak regulation and ensure the heating demand, and in non-heating period, the auxiliary units of Regenerative Electric Boiler and condensate system are used in the deep peak regulation, the utility model solves the problem that the utility ratio of the current regenerative electric boiler can only be put into use during the heating period, and also solves the problem that the power plant participates in the deep peak regulation in summer.

(2) taking a $350 \mathrm{MW}$ thermal power unit with a $70 \mathrm{MW}$ solid heat storage electric boiler as an example, the feasibility of its application in summer is verified. The calculation results show that the auxiliary units of the thermal storage electric boiler can participate in deep peak regulation 10 hours a day during summer operation, to get the corresponding peak-shaving revenue.

This work is supported by the Science and technology project of State Grid Jilin Electric Power Company Limited. The project number is KY-GS-21-01-05.

\section{References}

1. WU Ju. Flexibility transformation technology research and strategy analysis of thermal power units in Northeast China.Heilongjiang Electric Power.2020;42(5):443-446.

2. WANG Xingguo, SHI min, et al. Research on Peak Valley Dispatching Ancillary Service Strategy with Hebei Southen Power Grid Coal Fired Generator Unit.Hebei Electric Power.2018;37(6):1-4.

3. LIU Peng. R esearch on Coal Fired Generator Participating in Peak Valley Dispatching Ancillary Service Strategy.Northeast Electric Power Technology.2018;39(4):34-37.

4. XING Zhen-zhong,LENG Jie,ZHANG Yong-xing, et al. Research on Depth Peak Load Cycling of Thermal Power Generator Units.Northeast Electric Power Technology.2014;(4):18-23.

5. LIU Shengguan, QIAO Lei, ZHAI Pengcheng, et al. Technology and engineering application of heating with thermal storage electric boiler. Thermal Power Generation .2020;49(8):91-96.

6. ZHENG Zhidan. Application of Electric Boiler with Thermal Energy Storage inFacilitating Wind Power Integration Capability.Electrical appliances and energy efficiency management technology.2018;24:78-84.

7. Bin Tang,Jun Yi.Heat supply system of thermal storage electric boiler and its technical and economic application.Engineering Equipment and Materials.2017;11:111-112. 
8. YANG Shi-hao,SUN Xiao-ping,TIAN Feng, et al. Peak regulation of electric boiler in cogeneration.Journal of Shenyang Aerospace University.2021;38(1):63-69.

9. Dejun Liu.Research on deep peak shaving technology of thermal power unit.Chinese engineering equipment.2020;22:181-183. 